\title{
INCLUSIVE SCENARIO OF NATURAL PRODUCTS OBTAINED FROM AGAR PLANT (AQUILARIA SP.) IN BANGLADESH- A REVIEW
}

\author{
MN Hoque ${ }^{1}$, MF Mondal 2 , GHM Sagor ${ }^{3}$, MM Hasan $^{2}$ and A Hannan ${ }^{3 *}$ \\ ${ }_{1}^{1}$ Department of Biochemistry and Molecular Biology, Khulna Agricultural University, Khulna-9100, Bangladesh \\ ${ }^{2}$ Department of Entomology, Sylhet Agricultural University, Sylhet-3100, Bangladesh \\ ${ }^{3}$ Department of Genetics and Plant Breeding, Bangladesh Agricultural University, Mymensingh-2202, Bangladesh
}

\begin{abstract}
Agarwood is the resinous heartwood obtained from the injured parts of trees under Thymelaeaceae family particularly from Aquilaria species. Agarwood is considered as the most prized non-timber forest product (NTFP) used in attars as well as medicines. Quality of agarwood is the determiner for defining its commercial value. Different countries use different grading system to explain the quality of agarwood. In Bangladesh, more than 45 compounds have been identified so far, mostly sesquiterpenoids, alkanes, fatty acid and other volatile aromatic compounds that are responsible for its fragrance and high prices. Ether extract, total phenolic contents, flavonoid, antioxidant and microbiological tests have shown tremendous positive results. Chemical profiling of agar products is the best identified using GC-MS technique by the various authors. Present review discusses the full scenario of Aquilaria production, inoculation, extraction methods, determination of agarwood quality and chemical constituents of agar oils and possibilities and barriers of this industry in Bangladesh.
\end{abstract}

Key words: Agarwood, Agar oil, Cultivation, Microbiology, Phytochemistry

\section{Introduction}

The genus Aquilaria (Lam.) belongs to the Thymeleaceae family that has high commercial, economical and medicinal significance. Aquilaria species are mostly well known for the production of agarwood, a plant natural product extracted from agar tree that is highly valuable and priced product (Chowdhury et al. 2017). Near about twenty-one species of Aquilaria trees are introduced, out of which eight are recognized as agarwood producer (Zich and Compton 2002). These Aquilaria have been cultivated from 3000 years ago in the Middle East, China and Japan (Le 2003) and that is thought native to the Indo-Malaysia region (Mohamed and Lee 2016). Earlier Indian sub-continent was thought as the main source of agar tree for many times but now this tree is cultivated throughout the world especially in Bangladesh, India, Myanmar, Bhutan, Papua New Guinea, Thailand, Laos, Vietnam and so on (CITES 2004). Economically the Aquilaria is important for the agarwood and Agar oil in the worldwide perfumery markets. The most prized part is the aromatic resinous dark colored heartwood of agar tree that is the consequential substance of plant defense counter to external attacks and impacts such as mechanical wound inserted by human being or outer factors, pathological agents, insects and bacteria (Dinh 2010). In Bangladesh, agar (Aquilaria malaccensis, A. sinensis, A. agallocha) is mostly cultivated in the greater Sylhet region and some parts of Chittagong and Chittagong hill tracts (Mohamed and Lee 2016) that has rehabilitated the lifestyles of many people related to

*Author for correspondence: afsana.gpb@bau.edu.bd 
the sector (Siddiquee 2011). Agar farming is a private sector where more than 30,000 peoples are earning their livelihood under working in 121 agar processing factories that has established in different regions of Sylhet, Bangladesh and has changed their socio-economic status (Abdin 2014). As a profitable form of farming, agar industries are export oriented, highly laborious and being cultivated on commercial basis (Abdin 2014). In Bangladesh, the contribution of these industries to GDP is about $\$ 3750000$ per year (Siddiquee 2011) that is contributing in poverty reduction. Bangladesh exports their products both as wood chips and oils form. Agar oil is a concentrated volatile aromatic compound extracted from the stem of agarwood plant. Agarwoods are two categories; firstly screw injected agarwood that is common in Bangladesh (Akter et al. 2013) and secondly, naturally insect infested agarwood where insect borer named Zeuzera conferta Wlaker naturally infest agar plant (Aquilaria sp.) (Mazid et al. 2011, Kalita 2015). Literature reports that international market price for agar wood chips ranges from US \$20-6000 per kg based on its quality (Akter et al. 2013). Quality depends on so many factors such as color, odor, long lasting aroma and chemical profiles of the oil. To ensure accurate results, chemical analysis of agar oils is used globally for confirming grading of the agarwood (Norazah et al. 2009, Nurlaila et al. 2013). This is massively demanded in several countries which is further treated as perfumery ingredients, aroma enhancers (Norazah et al. 2016), incenses and decorative displays and used as a raw material in traditional and modern medicines (Mohamed and Lee 2016) and so many other different uses. Several researches were done to evaluate the quality of different categories of agarwood sold by the local exporters of Bangladesh. Therefore, the objective of this review is to reveal the overall status of agar plant cultivation and related researches in Bangladesh.

\section{Plantation of Agar tree}

This is an evergreen tree of 49-131 ft. height and 1.0-8.0 ft. diameter (Chakrabarty et al. 1994, Sumadiwangsa 1997) and soft, light, elastic and white to yellowish-white colored wood. It has up to 3.546 inch long oblong-lanceolate leaves with undulating margin. Agar trees grow very fast, and start producing flowers and seeds as early as four years old (Akter et al. 2013). April-May is the flowering period and seeds mature in about three months (Selvan et al. 2014).

\section{History of agar plant in Bangladesh}

Agarwood production was started about 400 years ago at the Suzanagar union under Baralekha upazila of Moulvibazar district in Bangladesh. Earlier agarwood was produced in forest only (Abdin 2014). Due to having inadequate access of agarwood cultivation in forest land, people started social farming system of agarwood in their household lands. Consequently, it became a time consuming process to find out the best quality agarwood. Therefore to mitigate this problem, they developed production of agar oil from ten to fifteen years young trees. Although having such a prolonged history; agarwood sector of Bangladesh does not prosper accordingly due to few policy anomalies and other constraints. Now more than hundreds agar processing factories have already been recognized in different regions of Sylhet, Bangladesh (Abdin 2014) that is going to be a profitable form of farming to contribute in poverty reduction.

\section{Present status of agar plant in Bangladesh}

Recently agar plant is cultivated on a commercial basis in Beanibazar, Golapganj, Fenchuganj, Sadar of Sylhet, Komolganj, Rajnagar, Srimangal and Barlekha of Moulvibazar district. The Barlekha upazila is one of the major places for growing agar and the Sujanagar union is well known at home and abroad for it. According to the reports of the daily star (2011), about 1,000 families in the village of Sujanagar are earning their livelihood by working in the agar factories set up in their homes and around. Some other mentionable places are also involved in the same work including Saldigha, Bartal, Uttar Sujanagar, Dakshin Sujanagar, 
Tangortoli and Rafinagar. These industries have a great contribution to GDP of Bangladesh (Siddiquee 2011) and approximately 25,000 - 30,000 workers are directly involved in agar farming, processing and marketing of agar-based products in the country (Baksha et al. 2009). Agar processing factories have already been established in different regions of Sylhet, Bangladesh (Abdin 2014). Agarwood plantation has been started by BRAC from July, 2007 in Bangladesh at Kaiyachara (17 acre area with 83,400 seedlings), about 700,000 agar seedlings were planted in two nurseries, of 'Kaiya' and 'Sirgasia', at Kaiyachara tea estate because of its economic benefit and conservation value (Akter and Neelim 2008). Additionally, during the period of 1999-2011 Government agar gardens in Denuded forest areas of Sylhet, Chittagong and Chittagong Hill Tracks (CHTs) have been established by the Forest Department (Novel 2017) and Bangladesh Forest Research Institution (BFRI) marginally started same at Charaljani and Keochia research stations in Chittagong (Rahman et al. 2015). Moreover, several small scale and personal agarwood plantations were done at Modhupur (Mymensingh), Birisiri, Haluaghat (Netrokona), Sylhet, Habiganj and Chittagong Hill Tracks (Alam 2004, Islam 2013, Selina et al. 2013). The establishment of this plantation would be significant in terms of the ecofriendly conservation of the endangered species as well as making carbon sink to lessen greenhouse gases. Likewise, there are possible opportunities that would arise in the future for enlightening the livelihoods of meager people in the area by providing income generating means (Selina et al. 2013).

\section{Agar cultivation in Bangladesh}

For sustainable economic development, proper investigation of the current status of agar (Aquilaria sp.) cultivation in Bangladesh is indispensable (Talucder et al. 2016). The major agar growing area is south and south-east Asia including Bangladesh, Bhutan, India, Indonesia, Iran, Malaysia, Myanmar, the Philippines, Singapore and Thailand (Oldfield et al. 1998). About eight Aquilaria sp. among all fifteen species of the genus are acquainted with agarwood production ( $\mathrm{Ng}$ et al. 1997) including A. malaccensis, $A$. agallocha and A. secundaria which are currently the main species for agar cultivation (Broad 1995). In Bangladesh, frequently cultivated species are Aquilaria malaccensis (Alam 2004, Chowdhury et al. 2016) and Aquilaria agallocha (Bhuiyan et al. 2009, Rahman et al. 2015).

\section{Climatic and edaphic factors for agar cultivation}

Aquilaria species typically grow between altitudes of 0-850 $\mathrm{m}$ in locations with average daily temperatures of $20-22^{\circ} \mathrm{C}$ (Keller and Sidiyasa 1994, Afifi 1995, Wiriadinata 1995). It prefers a subtropical climate with high humidity and rainfall range of 1800-3500 mm (Selvan et al. 2014). Naturally wide range of soils under wide climatic condition including those that are rocky, sandy or calcareous, well-drained slopes and ridges and land near swamps are used for growing Aquilaria sp. (Talucder et al. 2016). Suitable climatic and edaphic factors for agar cultivation were reported in previous study (Talucder et al. 2016) (Table 1). Although it is found in natural forests at an altitude of a few meters above sea level to about 1000 meters, it grows best around 500 meters (Selvan et al. 2014). Judicious quantity of sunshine and well-drained soil are the necessities for most of the agarwood saplings although they can grow under some shady condition in plantation (Selvan et al. 2014, Rima et al. 2015). Actually, sloppy lands are endorsed for agar plantation (Jansen 2003) as significant mortality rate was reported due to water logging (Akter and Neelim 2008). In Northern-East part of the country Aquilaria have been successfully implanted in plantations (Blanchette et al. 2015). Around $75 \%$ of the plantations have been established on degraded land as well as denuded hills and rest $25 \%$ were established at the homesteads of farmers (Rahman et al. 2015). Agar tree can also be grown 
on border side of field, garden, roads, school and office compounds; along bankside of ponds, tanks, canals; parks and residential sites. In hilly areas/tillas as in Barak valley it can be planted on poor soils on hill slopes, tilla tops.

Table 1. Suitable climatic and edaphic factors for Aquilaria species cultivation

\begin{tabular}{lc}
\hline Climatic variables and soil factors & Range of values \\
\hline Altitude range & $29-1000 \mathrm{~m}$ \\
Annual rainfall & $1500-6500 \mathrm{~mm}$ \\
Annual temperature & $22-28^{\circ} \mathrm{C}$ \\
Maximum temperature of hottest month & $22-40^{\circ} \mathrm{C}$ \\
Minimum temperature of coldest month & $14-22^{\circ} \mathrm{C}$ \\
Absolute minimum temperature & $5^{\circ} \mathrm{C}$ \\
Soil texture & Light; medium \\
Soil drainage & Free \\
Soil reaction & Acid; neutral \\
Special soil tolerances & Shallow; other \\
\hline
\end{tabular}

Source: Adopted from Talucder et al. (2016), Akter and Neelim (2008).

\section{Propagating material and plantation technique}

Talucder et al. (2016) reported that there was no other modern technique of propagation except conventional propagation by seed in Bangladesh. Multiplication of the plant occurs through mature seed (Ahmed 2010). Seeds are recalcitrant, have low period of viability (7-10 days) which becomes available in the month of June-July (Ahmed 2010, Talucder et al. 2016). Immediately after the fruit opening, seeds are collected for plantation because of difficulty in seed storage due to quick loss of viability. Sand beds are used for seed germination following transferring to polybags (Anonymous 2004, Talucder et al. 2016). Seed germination process is epigeal indicating necessity of special nursery management care. After just 25 days of cotyledons drop down, seedlings are transplanted into poly bags organized under temporary shade (Talucder et al. 2016). Poly bags are then arranged in bamboo pole surrounded beds with adaptation of the normal management practices. To avoid the penetration of roots into the soil, bags are shifted at monthly interval followed by light watering. Agar trees were planted in monoculture and block plantations (Rahman et al. 2015). After cleaning the planting sites, standard-size pits were dug at a spacing of $2 \mathrm{~m} \times 2 \mathrm{~m}$ and each pit was left unrestricted for at least 15 days after placing $1.5-2.0 \mathrm{~kg}$ of cowdung. Inorganic fertilizers can also be used during establishment of plantation. One-year-old seedling usually planted in April or May. Rahman et al. (2015) found that the conventional management practices were adapted mostly based on local knowledge and technology to manage agar plantations. Weeding to reduce the competition between the agar trees and other undesired plant species was the most frequently applied operation in agar plantations. Intensive weeding was carried out in the first 3 years. Staking was not a common practice in agar plantations (Rahman et al. 2015). Mulching at the bottom of agar plant is the most frequent practices for water loss reduction. During the seedling and sapling stages both organic and inorganic fertilizers were applied to promote growth. The organic fertilizers included fresh cowdung, plant debris and compost made from cowdung. The common inorganic fertilizers used in agar plantations included urea, tripple superphosphate (TSP) and muriate of 
potash (MP). In order to protect agar trees from leaf sucker insects, farmers used pesticides including malathion and endrin. Pruning was done only once a year, from the third to fifth or sixth year after out planting. According to the farmers, the best time for the pruning is the end of May. Thinning was rarely practiced in agar plantations. Farmers used boundary fencing to protect seedlings from herbivores and other disturbances (Rahman et al. 2015). About 12-15 years are required for agar wood tree to be used as raw materials. Ironing (putting iron rod inside the tree, about 100-150 kg iron rod/medium sized tree) is done at 810 years old tree. Then after 3-4 years, agar tree become suitable for agar oil extraction (Abdin 2014).

\section{Agarwood}

Agarwood sometimes known as eaglewood is the resinous heartwood of agar tree, relatively light and pale colored, formed in response to natural infection (such as pathological infection by the insects, bacteria etc.) or artificial induction like, mechanical injury (Akter et al. 2013). The wood is very condensed and dark when it is being matured and produced a dark aromatic resin (Blanchette 2006, Chowdhury et al. 2017).

\section{Inoculation methods of agar plants in Bangladesh}

The healthy woods or white wood of Aquilaria trees are without oleoresins. Agarwood farmers from different Asian countries are tried several wounding methods to produce agarwood, including chopping, nailing, holing and trunk breaking (Ahmad et al. 2017). In Bangladesh, generally two categories of agarwood (Aquilaria sp.) are produced by the agar workers. One is artificially screw injected agarwood (Akter et al. 2013) and the other is naturally insect infested agarwood (Hoque et al. 2019). Broadly, inoculations of agar trees are of two types- i) natural inoculation and ii) artificial inoculation.

\section{Natural inoculation}

Under natural conditions, oleoresin can only be produced by natural wounding such as injury by external factors, insect attack or bacterial/fungal infection around the wounded or rotting parts of the trunk (Blanchette 2006). Naturally agarwood production quantity is low (Gibson 1977). Naturally agar plant (Aquilaria sp.) is infested by insect borer Zeuzera conferta Wlaker (Kalita 2015, Hoque et al. 2019) in the wood when trunks of standing trees are bored by the larvae (Fig. 1a) (Selvan et al. 2014). It is seen that insect larvae bore the standing tree trunk of Aquilaria and make tunnels inside the tree trunks (Fig. 1b) (Hoque et al. 2019). Fungus (such as Fusarium sp., Rhizopus sp., Aspergillus sp., Mucor sp. and Penicillium sp.) can enter the plant through the erect hollow/zigzag channel inside the stem, which work for easy extent of infections and responsible for physiological host-parasite interaction (Selvan et al. 2014). After time being, infection can spread on all sides slowly and progressively and finally a large wood volume gets infected. An addition of oleoresins goes on increasing with the increase of infection rate as well as matures of infection. The more of oleoresins are deposited the concentration of color of the infected wood increases and to end with becomes black and odoriferous due to upsurge in concentration (Selvan et al. 2014). 

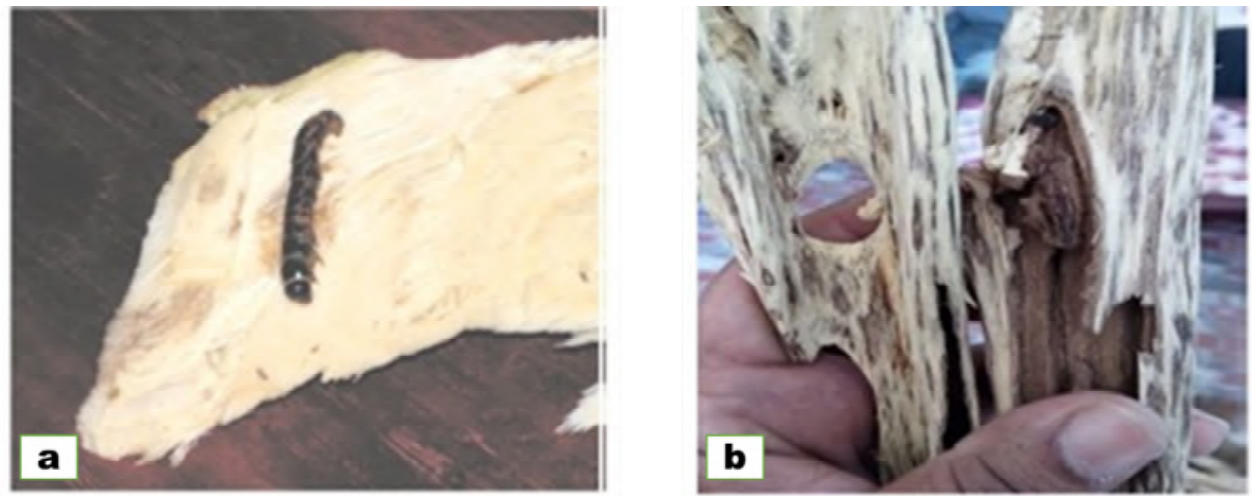

Figs. 1(a-b): Natural inoculation of agarwood. (a) Zeuzera confetra larva, and (b) Naturally insect infested agarwood.

\section{Artificial inoculation}

Artificial inoculation technique has found to be most productive and reliable method for the enrichment of agar production (Hoque et al. 2019). In Bangladesh people are practicing screw injected method so that they can produce resin artificially (Rahman et al. 2015). In this method, agarwood tree is wounded by hitting of iron nails (Rahman et al. 2015) into the trunks spirally with hundreds to thousands of nails put into each tree (Fig. 2a) (Blanchette et al. 2015). Screw is metal that is injected into the trunk of agar plants. Plant secrets resin in uniform pattern to protect themselves from external attack and contain different chemicals known as secondary metabolites (Fig. 2b) (Mazid et al. 2011, Hoque et al. 2019). Metallic component is unable to synthesis any chemical during its injection in agar tree. After many years, each metallic wound produces a minor amount of low quality resinous wood (Hoque et al. 2019). Moreover, agarwood produced from this practice is generally of inferior quality and unable to meet the preferred market demand (Persoon 2007). In the situation of increasing demand and price, some efforts are needed to stimulate agarwood production artificially as well as to drive a quicker process of its formation (Ahmad et al. 2017).
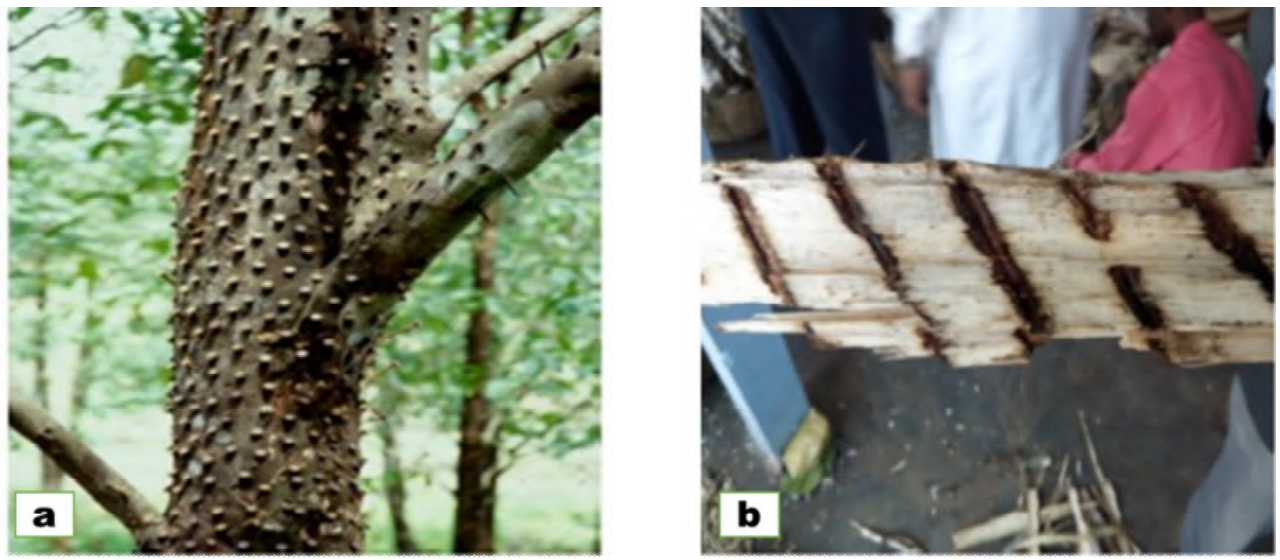

Figs. 2(a-b): Artificial inoculation technique of agarwood. (a) Screw injected into agar plant, and (b) Resin produced in screw injected agarwood. 


\section{Agar oil extraction method}

As agar products are traded both as chips and oil form, extraction of agar oils from agarwood has a great importance. Generally most of the trade essential oils are volatile, practically stable to the action of heat and insoluble in water therefore are fit for processing by distillation. There are three methods (Baksha et al. 2009) through which agarwood oils can be extracted namely, 1 . Hydro-distillation, 2. Steam distillation and 3. Super critical $\mathrm{CO}_{2}$ extraction. Out of three, the method practices in Bangladesh are Hydro-distillation method (Fig. 3) to extract agarwood essential oil (Hoque et al. 2018) which is the simplest and cheapest process of distillation (Chen et al. 2013). Essential oils are extracted from healthy or artificially injured plants using this method. At first, wood containing resin were chopped into wood chips and then soaked into water for 10-12 days (Hossen and Hossain 2016).

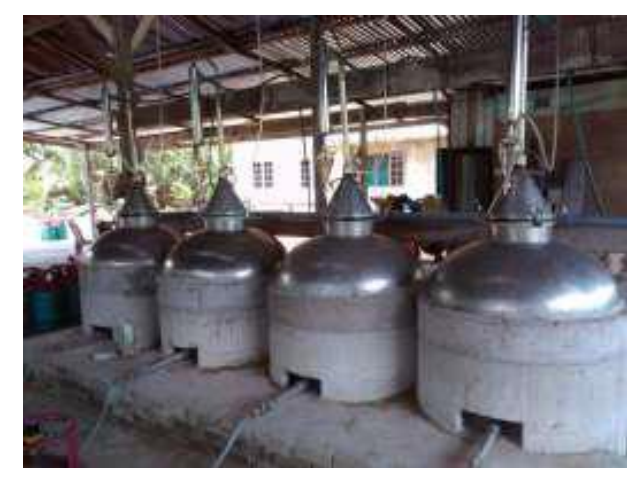

Fig. 3: Hydro-distillation chamber of agar oil extraction.

After this, the soaked chips were taken out, shattered and pounded manually or in machine. The chips were put in mini plants or Retort (Deg), where it is boiled constantly for 4-5 days. The heat and steam cause the cell structure of the plant material to burst and break down, thus freeing the essential oils (Chen et al. 2013). After oil vaporization, condensation occurred in distillation pipe (condenser) (Xiaojin et al. 2017). The extracted liquid is a mixture of oil and water is settled on water in collection pot (Hossen and Hossain 2016). Essential oils are easily separable from water and siphoned off for being water insoluble. They have the capability of floating on the surface because of being lighter compared to water. Then the sample was collected manually, sundried and bottled. Best quality comes from 1st distillation. A flow chart showing agar oil extraction process is given at Fig. 4 (Chen et al. 2013, Hossen and Hossain 2016, Hoque et al. 2018). 


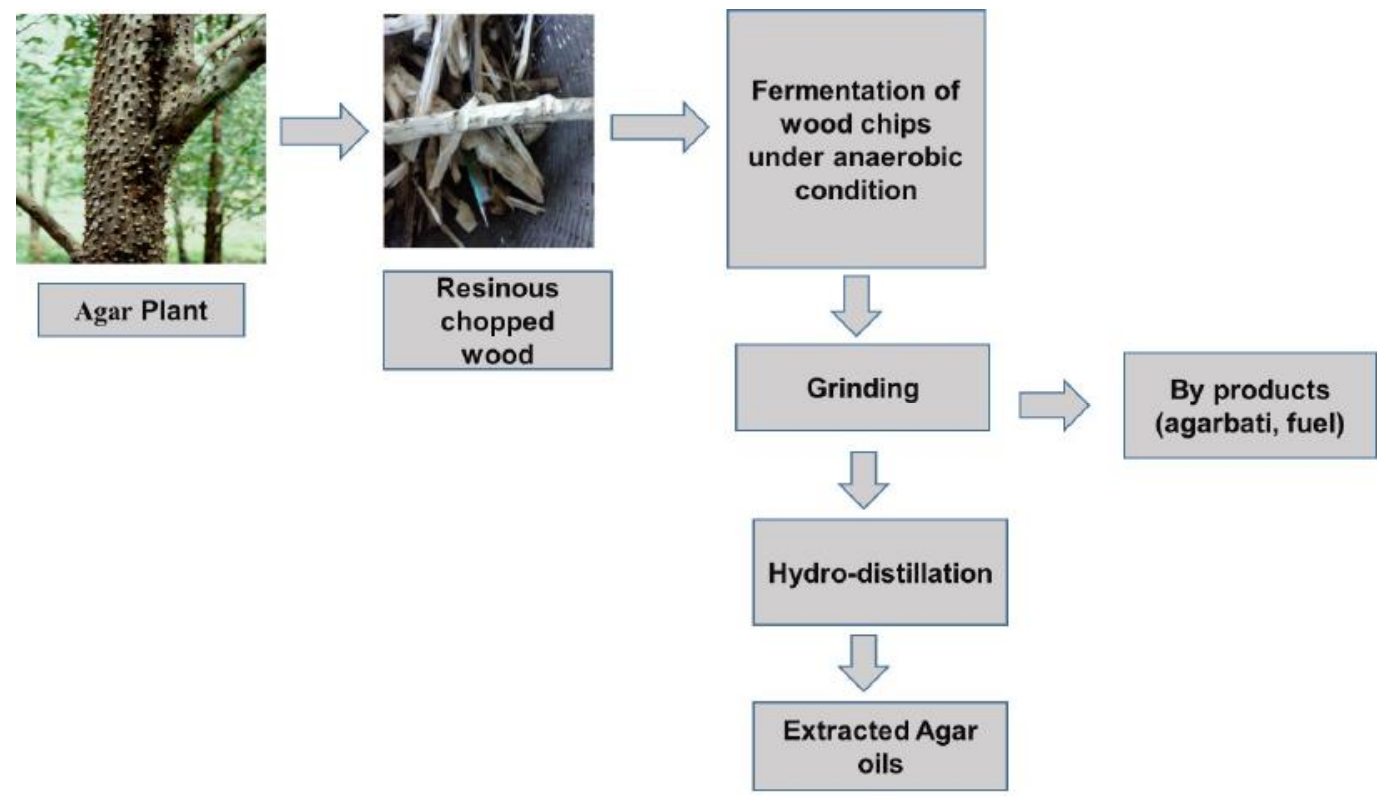

Fig. 4: Flow chart of agar oil extraction process.

\section{Agar oil}

Agar oil is highly intense volatile fragrant compound extracted from the heartwood of Aquilaria plant. Agar oil is used as incense, perfumery and for traditional medicines (Pripdeevech et al. 2011). It is an important ingredient in the perfumery industry and to generate aroma in wedding ceremonies or banquets (Yusoff et al. 2006, Takemoto et al. 2008, Norazah et al. 2012, Zhang et al. 2012). Multiple usages have been found from the agarwood trunk, branches, chips and flakes of uniform quality powder to essential oil (Wetwitayaklung et al. 2009). Many studies have shown that there has been a dramatic increase in agarwood oil usage in Malaysia (Najib et al. 2011, Tajuddin et al. 2013, Desa et al. 2021). Similarly there is an increasing trend of agarwood plantation in this country and also the market demand of its oil is enhanced (Hamid 2011, Rashid and Zuhaidi 2011).

\section{Chemical analysis of agar products of Bangladesh}

\section{Ether extract, total phenolic, flavonoid and antioxidant status}

Agarwood samples produced high percentages of ether extract which indicates its oil producing capabilities. Results from Bangladeshi wood samples of insect infested and nail injected woods showed fluctuations may be due to different level of insect infestation and using higher mass of insect infested wood sample (Ahmed et al. 2019) (Table 2). More insect injuries can produce higher oils (Hare 2011), phenolic, flavonoid contents and secondary metabolites which may contribute to the long oil shelf-life, color and several organoleptic characteristics (Bulotta et al. 2014, Hoque et al. 2019). Insect create initial site of infection of microbes such as-fungi and gradually moves upward (Kalita 2015, Hoque et al. 2019) that might have positive correlation between beneficial insect attack with phenol and flavonoid production (Zhao et al. 2018, Hoque et al. 2019). Microbes can also grow around the nail that can helps to produce black resinous oils (Zhang et al. 2010, 
Kalita 2015) but the percentage of natural microbes attack in nail injected agar tree is very low (Kalita 2015, Hoque et al. 2019) as metal (nails) is unable to secret any chemical during its injection in agar tree.

Table 2. Ether extract, total phenolic, flavonoid and antioxidant status of agar wood/oil in Bangladesh

\begin{tabular}{|c|c|c|c|c|}
\hline Analysis types & $\begin{array}{l}\text { Insect infested } \\
\text { wood }\end{array}$ & $\begin{array}{l}\text { Screw/Nail injected } \\
\text { wood }\end{array}$ & White wood & Reference (s) \\
\hline \multirow[t]{2}{*}{ Ether extract (\%) } & $11.08 \pm 0.94$ & $20.49 \pm 0.04$ & $1.80 \pm 0.03$ & $\begin{array}{l}\text { Hoque et al. } \\
\text { (2019) }\end{array}$ \\
\hline & $18.90 \pm 0.60$ & $11.03 \pm 0.19$ & $1.84 \pm 0.04$ & $\begin{array}{l}\text { Ahmed et al. } \\
(2019)\end{array}$ \\
\hline \multirow[t]{2}{*}{ Phenolics (mg/g) } & $2.97 \pm 0.07$ & $3.6 \pm 0.052$ & $2.55 \pm 0.05$ & $\begin{array}{l}\text { Hoque et al. } \\
\text { (2019) }\end{array}$ \\
\hline & $3.5 \pm 0.06$ & $2.98 \pm 0.07$ & $2.50 \pm 0.05$ & $\begin{array}{l}\text { Ahmed et al. } \\
(2019)\end{array}$ \\
\hline $\begin{array}{l}\text { Flavonoid content in } \mu \mathrm{g} \\
\text { QE/ml }\end{array}$ & $7.82 \pm 0.23$ & $6.58 \pm 0.62$ & - & $\begin{array}{l}\text { Ahmed et al. } \\
\text { (2019) }\end{array}$ \\
\hline $\begin{array}{l}\text { Antioxidant activity IC50 } \\
(\mu \mathrm{g} / \mathrm{ml}) \text { of agar oil }\end{array}$ & & 0.904 & & $\begin{array}{l}\text { Ahmed et al. } \\
(2019)\end{array}$ \\
\hline
\end{tabular}

\section{Phytochemistry of agar (Aquilaria sp.) in Bangladesh}

Chemical constituents of the infested agarwood oils are different from the artificially nailing wood of Aquilaria (Bhuiyan et al. 2009). Present review focuses on the chemical constituents of agar oil from the cultivated agar wood in Bangladesh. More than 45 compounds have been identified (Table 3) so far, mostly sesquiterpenoids, alkanes, aromandendrene and other volatile aromatic compounds (Bhuiyan et al. 2009, Hoque et al. 2018). Researches on exportable agar oil of Bangladesh revealed that sesquiterpenes and aromatic compounds occupied the major portion (above $90 \%$ ) and the rest portion is occupied with minor alcoholic and fatty acid group (Bhuiyan et al. 2009, Hoque et al. 2018). Sesquiterpenes is 15-carbon skeletons further classified into selinane, nootkatane, cadinanes, guaianes, prezizanes and agaropsiranes categories based on the basic structure. Sesquiterpenes are thought to be less volatile than other terpenes, have a greater potential for stereo-chemical diversity and have stronger odors. They are anti-inflammatory (Jeena et al. 2013), strong antioxidant (Ornano et al. 2013), anti-tumor activity (Park et al. 2011) and have bactericidal properties (Ishnava et al. 2013). Sesquiterpenes in the agarwood of Bangladesh is 94-95\% which is found higher than Chinese 80-89\% (Chen et al. 2011), Malayasian 80-85\% (Nor et al. 2015) agar oil (Bhuiyan et al. 2009, Hoque et al. 2018). Alcoholic compound such as 3-Tetradecyn-1-ol and 2Octylcyclopropene-1-heptanol possess bactericidal rather than bacteriostatic activity against vegetative cells (Raja et al. 2011). Occurrence of 4-phenyl-2-butanone compound, responsible for waxy herbal odor type medium odor strength (Yumi et al. 2014). 
Table 3. Chemical compounds identified in agarwood

\begin{tabular}{|c|c|c|c|}
\hline $\begin{array}{l}\text { Sl. } \\
\text { No. }\end{array}$ & Chemical constituents & Chemical structure & Reference(s) \\
\hline 1 & 4-phenyl-2-butanone & & $\begin{array}{l}\text { Hoque et al. } \\
(2018)\end{array}$ \\
\hline 2 & $\begin{array}{l}\text { N-benzyloxycarbonyl-serine, } \\
\text { methyl ester }\end{array}$ & & $\begin{array}{l}\text { Hoque et al. } \\
\text { (2018) }\end{array}$ \\
\hline 3 & $\begin{array}{l}\text { 6,7-dimethyl-1,2,3,5,8,8a- } \\
\text { Hexahydronaphthalene }\end{array}$ & & $\begin{array}{l}\text { Hoque et al. } \\
2018\end{array}$ \\
\hline 4 & Ledene oxide- II & & $\begin{array}{l}\text { Hoque et al. } \\
(2018)\end{array}$ \\
\hline 5 & Aromandendrene & & $\begin{array}{l}\text { Bhuiyan et al. } \\
\text { (2009), } \\
\text { Hoque et al. } \\
\text { (2018) }\end{array}$ \\
\hline 6 & $\begin{array}{l}\text { 2H-3,9a-Mehtano-1-benzoxepin,octahydro- } \\
\text { 2,2,5a,9-tetramethyl }\end{array}$ & & $\begin{array}{l}\text { Hoque et al. } \\
\text { (2018) }\end{array}$ \\
\hline
\end{tabular}


7 Tricyclo [5.2.2.0(1,6) undecen-3-ol,2-methylene6,8,8-trimethyl

8 Tricyclo[4.4.0.0(2,7)]dec-8-ene-3-methanol, a,a,6,8-tetramethyl-

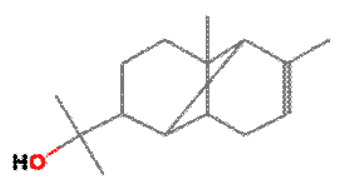

9 4-Isopropenyl-4,7-dimethyl-1oxaspiro[2.5]octane

10 Bicyclo[4.4.0]dec-5-ene,1,5-dimethyl-3-hydroxy8-(1-methylene-)

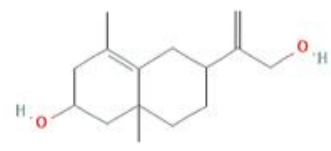

11 1,2,3,4,5,6,7,8-Octahydro-a,a,3,8-tetramethyl-5azulenemethanol

12 3,7-Cyclodecadiene-1-methanol, a, a,4,8tetramethyl-, [s-(Z,Z)]
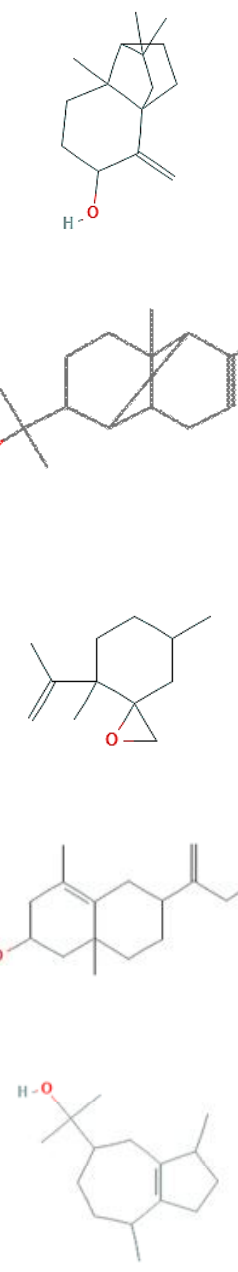

Bhuiyan et al. (2009), Hoque et al. (2018)

Hoque et al. (2018)

Hoque et al. (2018)

Hoque et al. (2018)

Bhuiyan et al. (2009),

Hoque et al. (2018)

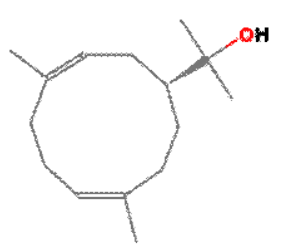

Hoque et al. (2018) 
13 Cyclohexanemethanol,4-ethenyl-a,a,4-trimethyl-

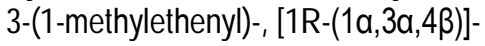

14 Isoaromadendrene epoxide

15 Tetradecyn-1-ol
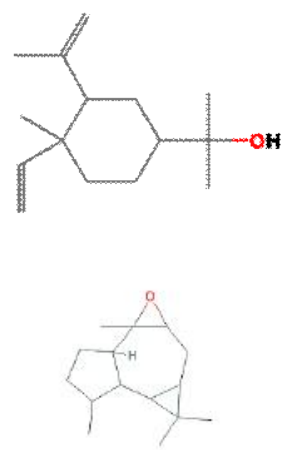

Hoque et al. (2018)

Hoque et al. (2018)

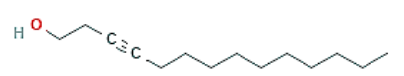

Hoque et al.

(2018)

Hoque et al.

(2018)
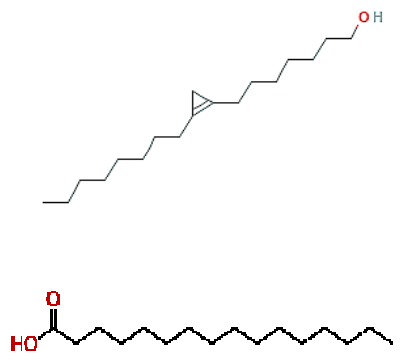

Bhuiyan et al. (2009),

Hoque et al. (2018)

Bhuiyan et al. (2009)

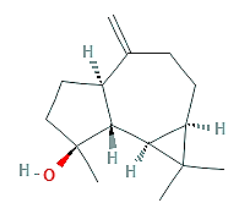

19 6,9-Octadecadiynoic acid, methyl ester
Bhuiyan et al. (2009) 
20 2-Naphthalenemethanol, 1,2,3,4,4a,5,6,7-

octahydro-.alpha..alpha.4a,8-tetramethyl-, (2Rcis)-<smiles>CC1=C2C[C@H](C(C)(C)O)CC[C@]2(C)CCC1</smiles>

Bhuiyan et al. (2009)

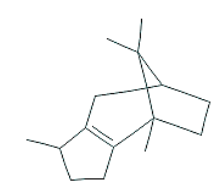

Bhuiyan et al.

$21 \beta$-Patchoulene

22 Naphthalene, 1,2,3,5,6,7,8,8a-octahydro-1,8a-<smiles>C=C(C)C1CCC2=CCCC(C)C2(C)C1</smiles>

(2009) dimethyl-7-(1-methylethenyl)-, [1R-(1a,7 $\beta, 8 a \alpha)]-$

Bhuiyan et al. (2009)

23 Azulene,1,2,3,3a,4,5,6,7-octahydro-1,4dimethyl-7-(1-methylethenyl)-,[1R$(1 a, 3 a \beta, 4 a, 7 \beta)]-$

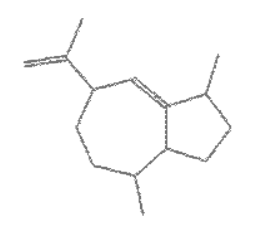

Bhuiyan et al. (2009)

24 Aristolene

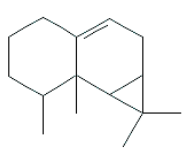

Bhuiyan et al. (2009)

25 Eremophilene

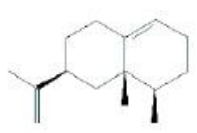

Bhuiyan et al. (2009)

26 5-Isobutyramido-2-methyl pyrimidine

Bhuiyan et al. (2009)

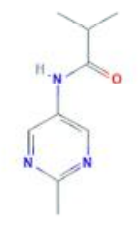


27 Isolongifolene, 9,10-dehydro-

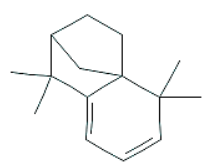

28 Diphenoxylic acid

29 Neoisolongifolene, 8,9-dehydro-

30 Isolongifolen-5-one

31 Naphthen-1-acetic acid, 8-methoxy-.alpha. methyl

32 3-Hydroxy-7-methoxy-2-naphthoic acid<smiles>COc1ccc2cc(O)c(C(=O)O)cc2c1</smiles>

33 Propanoic acid, 3-(diisopropylphosphino)-, methyl ester
Bhuiyan et al. (2009)

Bhuiyan et al. (2009)

Bhuiyan et al. (2009)

Bhuiyan et al. (2009)

Bhuiyan et al. (2009)

Bhuiyan et al. (2009)

Bhuiyan et al. (2009) 
34 3-Methoxy-6,7,8,9-tetrahydro-dibenzofuran-2-ol

35 Cadinene

36 Longiverbenone

37 Caryophyllene oxide

38 (6-Hydroxymethyl-2,3-dimethylphenyl)methanol

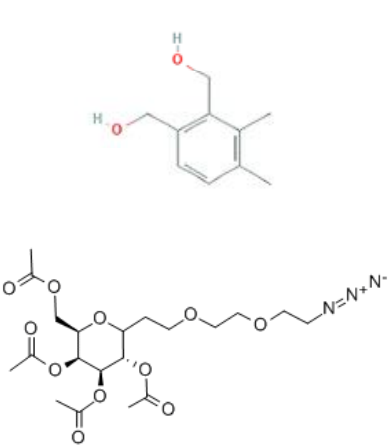

39 9-[4-[1,3-Diphenyl-2-imidazolidinyl]-2,3-0-[1methylethylidene]-.beta.-d
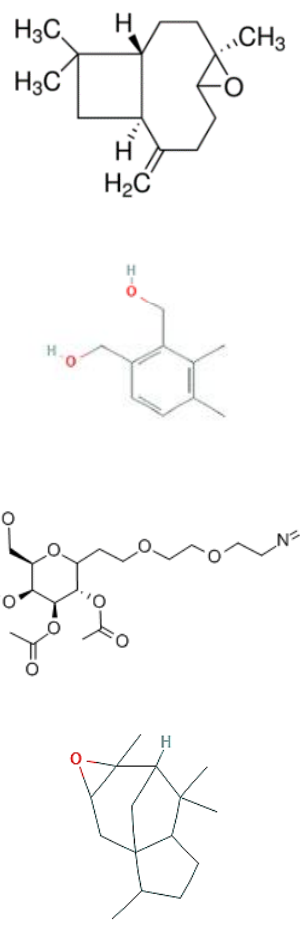

Bhuiyan et al. (2009)

Bhuiyan et al. (2009)

Bhuiyan et al. (2009)

Bhuiyan et al. (2009)

Bhuiyan et al. (2009)

Bhuiyan et al. (2009)

Bhuiyan et al. (2009) 
41 Viridiflorol

42 Octacosane

43 Diisooctyl phthalate

44 7-Isopropenyl-4a-methyl-1-

methylenedecahydronaphthalene

45 Cycloheptane, 4-methylene-1-methyl-2-(2methyl-1-propen-1-yl)-1-vinyl

46 Caryophyllene oxide
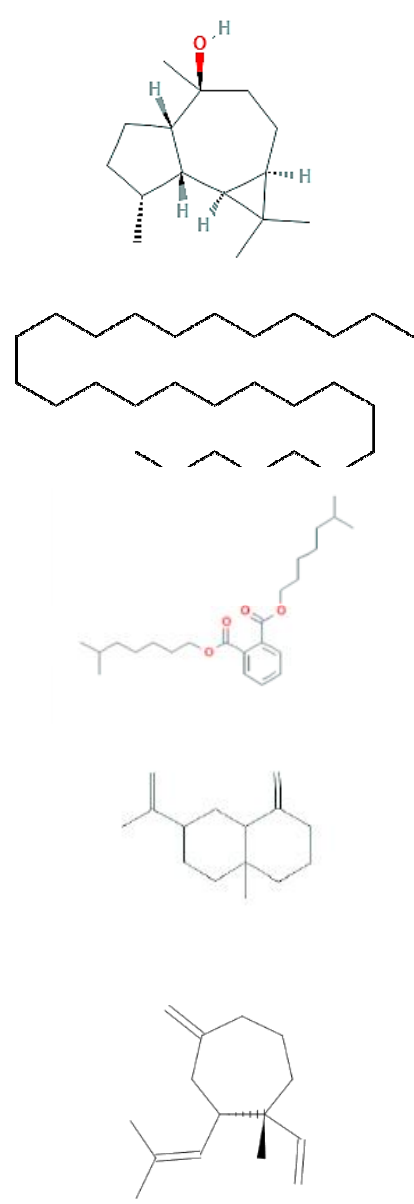

Bhuiyan et al. (2009)

Bhuiyan et al. (2009)

Bhuiyan et al. (2009)

Bhuiyan et al. (2009)

Bhuiyan et al. (2009)

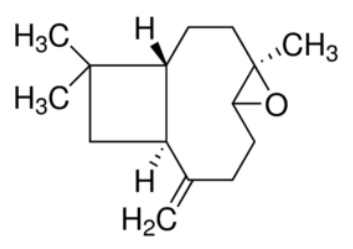

\section{Microbiological test of agar products}

Recent microbiological test of agar product was conducted by the researcher on antimicrobial activity test of the exportable agar oils from Bangladesh against some specific bacterial strains such as- Escherichia coli, Staphylococcus aureus, Salmonella and Vibrio (Hoque et al. 2018) and a bacterial isolate was identified for enhancing fermentation process of wood (Ahmed et al. 2019). Antimicrobial sensitivity test was done using agar well diffusion method and the results indicated non-significant sensitivity against all the tested bacteria 
(Hoque et al. 2018). On other hand, among tested bacteria - Bacillus sp., Klebsiella sp., Aeromonas sp., E. coli and S. aureus, only Bacillus sp. may contribute to increase the fermentation of agarwood to surge agarwood yield (Bhore et al. 2013). Chen et al. (2011) reported that if the active components from agar oil can be isolated and purified, their antimicrobial activities could be stronger.

\section{Agar quality analysis technique}

There is no internationally common system for ranking agar wood each sourcing country may have their own grading system or none at all (Hoque et al. 2018). These grades may not be accurate or inaccurate, but must be acceptable at both ends of the deal (Rozi and Shiou 2016). In Bangladesh, generally people categorized agarwood products according to its color, fragrance and fixative based on human's sense. Although this is a complex way to standardize its quality from the scent due to human nose cannot smell many tasters continuously (Norazah et al. 2009, Rahman 2009, Pripdeevech et al. 2011). There are several techniques, firstly, color is an indicator of oil or wood quality (Jayachandra et al. 2014) for example, dark color refers to the high quality because of high resin deposition (Boon et al. 2016) with very expensive market price (Norazah et al. 2008). Secondly, "sinking test" whereby wood chips have to drop in water to relate with the wood's quality. Wood that floats are considered as inferior in quality due to the low resin content (Rozi and Shiou 2016). Thirdly, "burning test" in which buyers can assess the aroma of agarwood by burning a small sample of the agarwood chip (Rozi and Shiou 2016). Fourthly, the long-lasting fragrance indicates that the quality is superior and naturally it influences the grade and pricing (Antonopoulou et al. 2010). Fifthly, the geographical source or place of origin and the characteristics of the agarwood including the size, shape, age and parts of the tree from where it is derived (Compton and Ishihara 2004, Wyn and Anak 2010). Sixthly, taste such as sweet, sour, salty, hot, and bitter, which turns grading into a very subjective matter and people dependent (Rozi and Shiou 2016). Therefore, different ways are available for grading or classifying the agarwood oil used in the country. Hence, no standard is available for high and low quality determination (Tajuddin 2011). Beside this grading system there are some other grading systems which are used by the local peoples dealing with trading and sell of agarwood. The most reliable and acceptable technique for the confirmation of agar oil is the chemical profile analysis (Hoque et al. 2018). Different color has different chemical constituents (Tajuddin and Yusoff 2010, Pornpunyapat et al. 2011). For an example, GC-MS analysis found that oxidoagaro chromone as a pale yellow in oil component (Yagura et al. 2005). Both color and odor have a complex mixture of sesquiterpenes and chromone derivatives (Tajuddin 2011). As for being major volatile components, the presence of sesquiterpenes is popular in market (Wetwitayaklung et al. 2009). The exportable oils from Bangladesh contained a complex mixture of different secondary metabolites (Hoque et al. 2018). Researches revealed that sesquiterpenes content used as grade indicator can be obtained only by chemical analysis of agar oils (Norazah et al. 2009, Nurlaila et al. 2013).

\section{Uses of agar products}

Agar products have many uses in industry as well as social purposes that have high economic values (Table 4). 
Table 4. Table showing uses of agar products

\begin{tabular}{|c|c|c|}
\hline Agar products & Uses & Reference(s) \\
\hline Agarwood chips & Raw materials in fragrance industry & Abdin (2014) \\
\hline Agar oil & $\begin{array}{l}\text { Body Fragrance, clothes fragrance and raw } \\
\text { materials in the perfume industry }\end{array}$ & $\begin{array}{l}\text { Antonopoulou et al. (2010), Abdin } \\
\text { (2014), Norazah et al. (2009) }\end{array}$ \\
\hline $\begin{array}{l}\text { Agarwood chips, } \\
\text { oudh, Bakhoor, } \\
\text { Scented chips }\end{array}$ & To receive honored guests & Antonopoulou et al. (2010) \\
\hline $\begin{array}{l}\text { Agarwood raw } \\
\text { powder }\end{array}$ & $\begin{array}{l}\text { Incense production and burning powder } \\
\text { during prayers in Buddhist temples }\end{array}$ & Abdin (2014) \\
\hline Agarwood beads & Religious purpose & Abdin (2014) \\
\hline Agarbati & Scented flame in religious purpose & Hossen and Hossain (2016) \\
\hline Unused branches & Firewood & Hossen and Hossain (2016) \\
\hline Agarwood medicines & $\begin{array}{l}\text { Several types of crude medicine, anti- } \\
\text { inflammatory, unanai ayuravedic, nervous } \\
\text { disorders, stimulants, stomach tumors }\end{array}$ & $\begin{array}{l}\text { Abdin (2014), Mohamed and Lee } \\
\text { (2016), Abas et al. (2017), Yadav } \\
\text { et al. (2013) }\end{array}$ \\
\hline Liquor with agarwood & $\begin{array}{l}\text { Liquor products produced by the Taiwan } \\
\text { Tobacco and Liquor Corporation }\end{array}$ & Song (2002) \\
\hline
\end{tabular}

\section{Agar industry in Bangladesh: possibility and barriers}

Present literatures have revealed very little amount of knowledge about agar industry in Bangladesh. Merely a few studies were being carried out like Akter and Neelim (2008) and Abdin (2014). It is totally an export oriented industry depending on the local raw materials and indigenous technology. In Bangladesh, more than 100 enterprises are involved in the production of agar wood and agar-oil which are mostly centered at Baralekha upazila of Moulvibazar district. Although having no availability of official export data, it is estimated that from Bangladesh local entrepreneurs are exporting about Tk. 5.00 million to Tk. 100 million (the stakeholders consultation meeting) per year from agar wood or agar-oil SME Foundation 2013 (Abdin 2014). Depending on topographical location and cultural deposition, first grade agar wood selling as woodchips, wood pieces, powder, dust, oil, incense ingredients and perfume is very costly (La Frankie 1994, Barden et al. 2000, Gunn et al. 2004, Compton 2007). Due to lack of diversified knowledge, Bangladeshi agar sector is producing only three items namely; agar wood chips, agar wood oil and agar wood powder/dust (Abdin 2014). Pricing of agarwood chips start at $\$ 30-\$ 9,000$ per $\mathrm{kg}$ based on resin content inside the chips (Babatunde 2015). Agar oil is also highly priced selling at US \$30,000 per $\mathrm{kg}$ (Chowdury et al 2016). The present global market is projected to US $\$ 6$ to $\$ 8$ billion for agar oil and other related agar products (Akter et al. 2013) and the commercial purchasers of agar oil is expected to exceed US $\$ 36$ billion in 2017 (http://www.ouddh.com = 2065877). In spite of the scenario, agar sector still remains as an unofficial/informal sector in Bangladesh. Lacks of governmental supports as well as limited governmental ingenuity to formalize the sector are the major constraints for industrializing agar products in Bangladesh. Currently, private sectors use their raw materials (trees) from their own gardens although governmental and social forests were the 
major primary source formerly. Also high import duty charge by the importing countries, limited access to the government forests while selling trees by the local agarwood entrepreneurs and lack of training facilities are also paving the way for agar industrializations (Abdin 2014, Chowdhury et al 2016, Das et al. 2018). Scarcity of high quality seedlings (Rahman et al 2015, Das et al 2018) and labor scarcity (Das et al. 2018) also have some contribution to make this sector unproductive. If this sector is prioritized as a promising one by the government of Bangladesh, relevant agencies and required steps are taken to mitigate the obstacles, then obviously the economy of Bangladesh will experience a huge flourishment.

\section{Conclusion}

Agar trees have attracted attention for its economic prices and scarcity. Agar is the most luxurious valued items of the world that could be one of the main sources for earning foreign currency and enrich export figure of Bangladesh if the country can flourish this sector. Data on exportable essential oils from Bangladesh is vital for receiving required market price and grade of the crops in the global market. As naturally infested agarwood is expensive than artificially inoculated agarwood, the production could be a multidimensional field in the prospects of Bangladesh through practicing the both techniques. The hilly fallow area of the country could be shifted to treasure house. Although numerous NGOs and private owned plantations have been financing for Aquilaria plantation in a number of districts in Bangladesh but the achievement of the effort basically depends on the agar wood production. Effective artificial induction method is needed to be introduced. This is the key time to think about financing on exploration of induction to reach economic goal of plantation. The selection of new plants from authentic sources, ideal inoculation and induction methods could spark the economy through quality enhancement. A multidisciplinary tactic could be introduced with the expert professionals of forestry, mycology, biochemistry and microbiology to achieve the goal.

\section{Acknowledgements}

Author is highly thankful to Dr. GHM Sagor, Md. Mehedi Hasan and Afsana Hannan, for helping in review, to write the manuscript and Dr. Md. Fuad Mondal for cordial guidance, kind co-operation and supervision for the completion of the research work and preparation of this paper.

\section{Competing interests}

Authors have declared that no competing interests exist.

\section{References}

Abdin J (2014). The agar wood industry: yet to utilize in Bangladesh. International Journal of Economics and Management Sciences, 3: 163.

Abas MA, Zubir NSA, Ismail N, Yassin IM, Ali NAM, Rahiman MHF (2017). Agarwood oil quality classifier using machine learning. Journal of Fundamental and Applied Sciences, 9: 62-76.

Afifi (1995). Proses pengoluhan pohon gaharu sampai siap diperdagangkan dan lata car apemhudidayaannya. serta proese gaharu pemhentukan guha. In: Lokakarya Pengusahaan Hasil Hutan Non Kayu (Rotan, Gaharu, dan Tanaman obat). Departemen Kehutanan. Indonesia-UK Tropical Forest Management programme. Surabaya, 31 July- 1 August, Access on BRAC research report July, 2008.

Ahmed J, Khan MMH, Kashem MA, Ahmed SR and JAKIR M (2019). Evaluation of density metric grading of agarwood, antioxidant potentiality in agar oil and prevalence of unknown bacteria in agarwood soaking water. Journal of Advanced Biotechnology and Experimental Therapeutics, 2: 44-50 
Ahmad F, Rizkita R, Esyanti, Elfa NA, Iriawati, Erdy S and Maman T (2017). Formation of agarwood from Aquilaria malaccensis in response to inoculation of local strains of Fusarium solani, Springer-Verlag Berlin Heidelberg, 31: 189-197.

Ahmed F (2010). Study of agar production in two selected areas Bangladesh. MS Thesis, Department of Farm Power and Machinery, Bangladesh Agricultural University, Mymensingh, Bangladesh.

Akter S, Islam MT, Zulkefeli M and Khan SI (2013). Agarwood production-a multidisciplinary field to be explored in Bangladesh. International Journal of Pharmaceutical and Life Sciences, 2: 22-32.

Akter $N$ and Neelim AZ (2008). Agarwood plantation at BRAC tea estate: introduction, environmental factors and financial analysis. BRAC Research Report, Dhaka. pp. 12-13.

Alam SM (2004). Production, processing and economic aspects of Agar tree (Aquilaria malaccensis) as an agroforestry species in Maulvibazar district of Bangladesh. Dissertation, Bangabandhu Sheikh Mujibur Rahman Agricultural University, Gazipur, 6-18, 31-42.

Anonymous (2004). Agar plantation. In: Ahmed M. (Eds.). Hand book on medicinal and aromatic plants, North Eastern Development Finance Corporation Limited, Guwahati, Assam, pp. 39-48.

Antonopoulou M, Compton J, Perry LS and Al-Mubarak R (2010). The trade and use of agarwood (oudh) in the United Arab Emirates, TRAFFIC Southeast Asia. Petaling Jaya, Selangor, Malaysia.

Baksha MW, Akhter S, Basak AC and Rahman MS (2009). Bangladesh agar chas o agar kutir silpo (Agar cultivation and agar cottage industry in Bangladesh), Bangladesh Forest Research Institute. Chittagong.

Babatunde OJ (2015). Oud: Arabia's traditional scent. Available at: http://www.masterpiece-ng.com/ 2015/09/01/oudarabias traditional-scent.

Barden A, Anak NA, Mulliken T and Song M (2000). Heart of the Matter: Agarwood Use and Trade and Cites Implementation for Aquilaria malaccensis, Cambridge: Traffic International.

Blanchette RA (2006). The genus Gyrinops, is closely related to Aquilaria and in the past all species were considered to belong to Aquilaria. Cultivated Agarwood -Training programs and Research in Papua New Guinea, Forest Pathology and Wood Microbiology Research Laboratory, Department of Plant Pathology, University of Minnesota.

Blanchette RA, Jurgens JA and Beek HHV (2015). Growing Aquilaria and production of agarwood in Hill Agroecosystems. In: Eckman K and Ralte L (Eds.), Integrated Land Use Management in the Eastern Himalayas. Akansha Publishing House, Delhi, pp. 66-82.

Boon YT, Naim MN, Zakaria R, Abu Bakar NF, Ahmad N and Lenggoro IW (2016). Grading of emulsified agarwood oil using gel electrophoresis technique. International Journal of Chemical and Molecular Engineering, 10: 547-550.

Bhore SJ, Preveena J and Kandasamy KI (2013). Isolation and identification of bacterial endophytes from pharmaceutical agarwood-producing Aquilaria species. Pharmacogn Research, 5: 131-137.

Bhuiyan MNI, Begum J and Bhuiyan MNH (2009). Analysis of essential oil of eaglewood tree (Aquilaria agallocha Roxb.) by gas chromatography mass spectrometry. Bangladesh Journal of Pharmacology, 4: 24-28.

Broad S (1995). Agarwood harvesting in Vietnam, TRAFFIC Bulletin 15: 96.

Bulotta S, Celano M, Lepore SM, Montalcini T, Pujia A and Russo D (2014). Beneficial effects of the olive oil phenolic components oleuropein and hydroxytyrosol: focus on protection against cardiovascular and metabolic diseases. Journal of Translational Medicine, pp. 12.

Compton J (2007). Trade Matters: Regulating a Legal and Sustainable Agarwood Industry. $2^{\text {nd }}$ International Agarwood Conference and Workshop. Bangkok and Koh Chang, Thailand.

Chowdhury M, Hussain MD, Chung S, Kabir E and Rahman A (2016). Agarwood manufacturing: a multidisciplinary opportunity for economy of Bangladesh- A review. Agricultural Engineering International, CIGR Journal, 18: 171-178. 
Chowdhury M, Rahman A, Hussain M and Kabir E (2017). The Economic benefit of agarwood production through aeration method into the Aquilaria Malaccensis tree in Bangladesh, Bangladesh Journal of Agricultural Research 42: 191-196.

Chakrabarty K, Kumar A and Menon V (1994). Trade in agar tree. TRAFFIC India and WWF India, New Delhi, pp. 51.

Chen W, Feng J, Gan B and Chen X (2013). Whole-tree Agarwood inducing technique: an efficient novel technique for producing high-quality agarwood in cultivated Aquilaria sinensis trees, Molecules 18: 3089-3101.

Compton J and Ishihara A (2004). The use and trade of agarwood in Japan. Cambridge: TRAFFIC International, 6: 1-21.

Das P, Sabur SA, Palash MS and Hasan M (2018). An economic analysis of agar-wood production in north-eastern Bangladesh, Asian Journal of Economics, Business and Accounting, 1-8.

Desa AP, Lee SY, Mustapa MZ, Mohamed R and Emang D (2021). Trends in the agarwood industry of Peninsular Malaysia. The Malaysian Forester, 84: 152-168.

Dinh XB (2017). A Vietnamese technique of agarwood inducement. Available at uww. agarwood.ning.com/profiles/blogs/http:agarwood inducement on 21 $1^{\text {th }}$ September 2017, 2010.

Gibson IAS (1977). The role of fungi in the origin of oleoresin deposits (Agaru) in the wood of A. agallocha Roxb, Bano Biggyan Patrika 6: 16-26.

Gunn B, Stevens P, Singadan M, Sunari L and Chatterton P (2004). Eaglewood in Papua New Guinea. Resource Management in Asia-Pacific (RMAP), 51: 14-17.

Hamid KHK (2011). Professional lecture: enhancing the world of fragrance through Malaysian Bio-Gaharu. Shah Alam, Selangor, Malaysia: University Publication Centre (UPENA), UITM.

Hare JD (2011). Ecological role of volatiles produced by plants in response to damage by herbivorous insects. Annual Review of Entomology, 56: 161-180.

Hoque MN, Khan MMH and Mondal MF (2019). Insect infested agarwood: A newly prized product of agarwood market in Bangladesh. Fundamental and Applied Agriculture, 4: 689-692.

Hoque MN, Mondal MF and Khan MMH (2018). Chemical Composition and Antimicrobial Activity of the Essential Oils from Aquillaria malaccensis in Bangladesh, Haya. The Saudi Journal of Life Sciences, 3: 600-608.

Hossen S and Hossain MK (2016). Initial growth performance of agar (Aquilaria malaccensis) plantations at public and private sectors in Bangladesh. Journal of Bioscience and Agriculture Research, 10: 871-876.

Jansen A (2003). Domestication of Aquilaria spp. and rural poverty-socio-economic and genetic aspects of the planting boom in the "wood of the gods". In: Nafri Workshop Proceedings. pp. 233-239.

Jayachandran K, Sekar I, Parthiban KT, Amirtham D and Suresh KK (2013). Analysis of different grades of agarwood (Aquilaria malaccensis Lamk.) oil through GC-MS. Indian Journal of Natural Resources, 5: 44-47.

Kalita J (2015). Association of Zeuzera conferta Walker on agarwood formation in Aquilaria malaccensis Lamk. Canadian Journal of Plant Science and Research, 5: 4-9.

Keller P and Sidiyasa K (1994). Trees of Balikpapan-samarinda area, east Kalimantan. Indonesia: A Mamwl 280 selected Species, The Tropenbos Foundation, Wageningen.

Lafrankie JV (1994). Population dynamics of some tropical trees that yield non-timber forest products, Economic Botany, 48: 301-309.

Lee CK (2003). History and ecology of agarwood in Vietnam. In: Proceedings of the $1^{\text {st }}$ International Agarwood Conference. The Tropical Rainforest.

Mazid M, Khan TA and Mohammad F (2011). Role of secondary metabolites in defense mechanisms of plants. Biology and Medicine, 3: 232-249. 
Mohamed R and Lee SY (2016). Keeping up appearances: Agarwood grades and quality. In: Agarwood. Springer, Singapore, pp.149-167.

Najib MS, Ali NAM, Arip MNM, Jalil AM and Taib MN (2011). Classification of Agarwood Grades using ANN. In: International Conference on Electrical, Control and Computer Engineering.

$\mathrm{Ng} \mathrm{LT}$, Chang YS and Kadir AA (1997). A review on agar (gaharu) producing Aquilaria species, Tropical Forest Products, 2: $272-285$.

Norazah MA, Chang YS, Mailina J, Said AA, Majid JA, Husni SS, Hasnida HN and Yasmin YN (2008). Comparison of chemical profiles of selected gaharu oils from Peninsular Malaysia. The Malaysian Journal of Analytical Sciences, 12: 338-340.

Norazah MA, Majid JA, Mailina J, Said AA, Husni SS, Hasnida HN et al. (2008). Profiles of selected supreme Agarwood oils from Malaysia, Herbal Globalisation: A New Paradigm for Malaysian Herbal Industry 2009: 393-398.

Novel SDA (2017) Jaulus phirache agar khate (In Bangla). Retrieved March 3, 2017, from http://www.bdpratidin.com/last-page/2017/03/03/212185.

Nurlaila I, Norazah MA, Mailina J, Mohd HFR, Saiful NT and Mohd NT (2014). A review study of agarwood oil and its quality analysis. Jurnal Teknologi (Sciences and Engineering), 68: 37-42.

Oldfield S, Lusty C and Mackinven A (1998). The world list of threatened trees. World Conservation Press, Cambridge, UK.

Pornpunyapat J, Chetpattananondh P and Tongurai C (2011). Mathematical modeling for extraction of essential oil from Aquilaria crassna by hydrodistillation and quality of agarwood oil. Bangladesh Journal of Pharmacology, 6: 18-24.

Pripdeevech P, Khummueng W and Park SK (2011). Identification of odor-active components of agarwood essential oils from Thailand by solid phase microextraction-GC/MS and GC-O. Journal of Essential Oil Research, 23: 46-53.

Raja AGK, Furqan AK and Khan AM (2011). Impact of training and development on organizational performance. Global Journal of Management and Business Research, 11: 975-585.

Rahman SFA (2009). Analysis of agarwood oil composition via preparative thin layer chromatography. http://umpir.ump.edu.my/id/eprint/806/1/Siti_Faridah_Ab_Rahman.pdf

Rahman M, Nath NM, Sarker S, Adnan M and Islam M (2015). Management and economic aspects of growing Aquilaria agallocha Roxb. in Bangladesh. Small-Scale Forestry, 14: 459-478.

Rashid AMA and Zuhaidi YA (2011). Tapping the wealth from Karas (Aquilaria malaccensis) tree. In: Forest Research Institute Malaysia, Selangor, Malaysia.

Raymakers C (2006). CITES, the Convention on International Trade in Endangered Species of Wild Fauna and Flora: its role in the conservation of Acipenseriformes. Journal of Applied Ichthyology, 22: 53-65.

Rima HSS, Ulfah JS, Iskandar ZS, Selangor, Malaysia and Erdy S (2015). Identification of morphological characters of Aquilaria microcarpa in the interaction with Fusarium solani, International Journal of Sciences: Basic and Applied Research, 20: 119-128.

Rozi M and Shiou YL (2016). The origin and domestication of Aquilaria, an important agarwood-producing genus. Springer, Agarwood, Tropical Forestry, pp. 453.

Siddiquee I (2011) Agar farming sees export markets. The Daily Star, Dhaka, Bangladesh. http://www.thedailystar.net/news-detail-207067. Accessed on 25 December 2018.

SONG (2002) Cited at the trade and uses of agarwood in Taiwan, Province of China, Report compiled by the TRAFFIC East Asia - Taipei and TRAFFIC Southeast Asia for CITES Secretariat (undated); PC - 15 Inf. 7.

Sumadiwangsa S (1997). Kayu gaharu komoditie lit di Kalimantan Timur. Duta Rimba. July- Augustus, pp. 205-206. 
Tajuddin SN, Muhamad NS, Yarmo MA and Yusoff MM (2013). Characterization of the chemical constituents of agarwood oils from Malaysia by Comprehensive Two- Dimensional Gas Chromatography-Time-of-Flight Mass Spectrometry. Mendeleev Communications, 23: 51-52.

Tajuddin SN (2011). Resolution of complex sesquiterpene mixture in Aqualaria malaccensis (Gaharu) volatile oils using gas chromatography methods. PhD Thesis, Faculty of Industry and Science Technology, University Malaysia Pahang.

Tajuddin SN and Yusoff MM (2010). Chemical composition of volatile oils of Aquilaria malaccensis (Thymeleaceae) from Malaysia. Natural Product Communications, 5: 1965-1968.

Takemoto H, Ito M, Shiraki T, Yagura T and Honda G (2008). Sedative effects of vapor inhalation of agarwood oil and spikenard extract and identification of their active components, Journal of Natural Medicines 62: 41-46.

Talucder MSA, Haque MM and Saha D (2016). Development of agar (Aquilaria malaccensis) cultivation, propagation technique and its potentiality as agroforestry component in Bangladesh: A review. Journal of Sylhet Agricultural University, 3: 149-157.

Selvan T, Nandini D and Kaushik PK (2014). Agarwood production for intensive income generation. Review of Research Journal, 3.

Wetwitayaklung $P$, Thavanapong $N$ and Charoenteeraboon J (2009). Chemical constituents and antimicrobial activity of essential oil and extracts of heartwood of Aquilaria crassna Obtained from water distillation and supercritical fluid carbon dioxide extraction. Silpakorn University Science and Technology Journal, 3: 25-33.

Wiriadinata H (1995). Gaharu (Aquilaria spp.) Pengembangan dan Pemanfaatan yang Berkelanjutan. Lokakarya Pengusahaan Hasil Hutan Non Kayu (Rotan, Gaharu, dan Tanaman Obat). Departemen Kehutanan.

Wyn LT and Anak NA (2010). Wood for trees: A review of the agarwood (Gaharu) trade. Kuala Lumpur, TRAFFIC Southeast Asia, 1-65.

Xiaojin L, Daping X, Zengjiang Y and Ningnan Z (2017). Chemical composition of essential oils from the heartwood of Pterocarpus macrocarpus by different extraction methods in southern China. Journal of Essential Oil Bearing Plants, 20: 110-115.

Yadav K, Mudgal D, Agrawal V, Maurya K, Bawankule AU and Chanotiya DS (2013). Molecular docking and ADME studies of natural compounds of agarwood oil for topical anti-inflammatory activity, Current Computer-Aided Drug Design, 9: 360-370.

Yagura T, Shibayama N, Ito M, Kiuchi F and Honda G (2005). Three novel diepoxy tetrahydrochromones from agarwood artificially produced by intentional wounding. Tetrahedron Letters, 46: 4395-4398.

Yusoff NH, Salleh MM, Yahaya M and Awang MR (2006). The use of photoluminescence spectra of $\mathrm{TiO}_{2}$ nanoparticles coated with porphyrin dye thin film for grading agarwood oil. In: Proceedings of ICSE, pp. 193-197.

Zhang XL, Liu YY, Wei JH, Yang Y, Zhang Z, Huang JQ, Chen HQ and Liu YJ (2012). Production of high-quality agarwood in Aquilaria sinensis trees via whole-tree agarwood-induction technology. Chinese Chemical Letters, 23: 727-730.

Zhang Z, Yang Y, Meng H, Sui CH, Wei JH and Chen HQ (2010). Advances in studies on mechanism of agarwood formation in Aquilaria sinensis and its hypothesis of agarwood formation induced by defense response. Chinese Traditional and Herbal Drugs, 41: 156-159.

Zhao X, Song JL, Yi R, Li G, Sun P, Park KY and Suo H (2018). Comparison of antioxidative effects of insect tea and its raw tea (Kuding tea) polyphenols in Kunming mice, Molecules, 23: 204.

Zich F and Compton J (2002). The final frontier: towards sustainable management of Papua New Guinea's agarwood resource. In: A Traffic Oceania report and WWF South Pacific programme, Sydney, Australia, pp. 1-12. 